Volume 3, Issue 1, February 2018, Pages: 250, DOI: http://dx.doi.org/10.19082/ah250

\title{
RESIDUAL MICROBIOLOGICAL CONTAMINATION OF DIGESTIVE ENDOSCOPES IN GASTROENTEROLOGICAL UNITS AT THE UNIVERSITY HOSPITAL CENTERS OF TLEMCEN, MAGHNIA AND GHAZAOUAT, ALGERIA
}

\author{
Sara Gaouar ${ }^{1}$, Hafida Hassaine ${ }^{1}$, Samia Bellifa ${ }^{1}$, Wafae Didi ${ }^{1}$, Amira Nanet ${ }^{1}$
}

1 Laboratory of Food and Environmental Microbiology (LAMAABE) University of Tlemcen, Algeria «sarah.gaouar@outlook.fr»

\section{TYPE OF ARTICLE: CONFERENCE ABSTRACT}

\begin{abstract}
Background: Digestive endoscopy remains a medical examination which can be at the origin of nosocomial infections. During a gastro-intestinal endoscopy, the device crosses natural cavities always with commensal bacterial flora and sometimes pathogenic flora. In all cases, the device is contaminated after the examination. The lack of effective disinfection exposes the risk of transmission of germs.

Aim: The objective of this study is to test the effectiveness of the disinfection procedure for endoscopes. This will be done by evaluation of residual microbiological contamination after disinfection and after storage of endoscopes in gastroenterological units of the UHCs of Tlemcen, Maghnia and Ghazaouat

Methods: The samples concerned all endoscope services. It was undertaken in two phases: the injection of a stall in the channels of the endoscope, and a swab of the distal and proximal end caps.

Results: We have isolated and identified more than 60 microorganisms with nosocomial risk and their ability to form biofilm was proved.

Conclusion: Respecting basic principles of hospital hygiene and application of rigorous cleaning and disinfecting processes are major elements in preventing and fighting infections related to endoscopy.

KEYWORDS: Endoscopy, Contamination, Disinfection, Biofilm, Nosocomial infection
\end{abstract}

